\title{
Supporting policies, regulations and milestones for Government 2.0 in the United States of America
}

Report prepared for the European Commission tender

\author{
Ines A. Mergel \\ Maxwell School of Citizenship and Public Affairs \\ Department of Public Administration and International Affairs \\ Syracuse University \\ 215 Eggers Hall \\ Syracuse, NY 13244 \\ U.S.A. \\ Contact: iamergel@maxwell.syr.edu
}

Government 2.0 the United States has evolved out of political, regulatory and 'acceptable use' changes, but also an increased level of maturity of social media tools. To highlight just the most prominent tools: LinkedIn, Friendster, and MySpace were launched in 2003, followed by Facebook in 2004, YouTube in 2005, and Twitter in 2006. We can add to this development the emergence of a whole conglomerate of other Web 2.0 tools, such as wikis, blogs or virtual worlds. This paper explores the supporting policies, regulations and milestones that have lead to Government 2.0 implementation in the United States of America. 


\section{Supporting policies, regulations and milestones for Government 2.0 in the United States of America}

Government 2.0 the United States has evolved out of political, regulatory and 'acceptable use' changes, but also an increased level of maturity of social media tools. To highlight just the most prominent tools: LinkedIn, Friendster, and MySpace were launched in 2003, followed by Facebook in 2004, YouTube in 2005, and Twitter in 2006. We can add to this development the emergence of a whole conglomerate of other Web 2.0 tools, such as wikis, blogs or virtual worlds.

What we now call Government 2.0 has roots that stretch back several years. Many local and state government IT professionals very early on tried to find ways to integrate social media into their existing communication, collaboration and community approaches. In 2007 former CTO of Washington, D.C., Vivek Kundra, used a Wiki to present requests for proposals in the acquisition process. ${ }^{i}$ In 2008, as part of the Government 2.0 eco-system, over 800 local government IT professionals found a way to share lessons learned and best practices in a virtual group, called MuniGov2.0. ${ }^{\text {ii }}$ At about the same time, GovLoop - the "Facebook for Government" was created and by now has $\sim 40,000$ users sharing information about Government 2.0 related topics.

In 2009 agencies and departments in the executive branch of the U.S. federal government have started to use social media applications, such as Facebook pages, Twitter updates, YouTube videos, blogs and RSS feeds. This development was triggered largely by President Obama’s

“Transparency and Open Government" memo published one day after his inauguration on January 21, 2009. ${ }^{\text {iii }}$ In this memo he highlights three distinct areas of open government that direct 
the executive departments and agencies to increase participation, collaboration and transparency. The memo provides a mandate only for the executive departments and agencies in the federal government. But we can also observe a movement that is self-inspired, driven by the need for more transparency and community building, at the local and state government level.

While every administration in the past forty years has developed a variation of Open Government, the Obama Administration has redefined information as a public asset that needs to be shared with the citizens. The memo specifically urges executive departments and agencies to "harness new technologies to put information about their operations and decisions online and readily available to the public. ${ }^{\text {iv }}$ What becomes clear in this memo is that the current administration does not see government as the sole provider of relevant and actionable information - on the contrary, all constituencies are regarded as important contributors to help to create, share and disseminate information.

Government 2.0 has quickly become a synonym for the use of the second generation of Internet technologies in government: highly interactive social networking services, that allow for real-time information sharing, crowdsourcing and bidirectional communication between citizens and with government. ${ }^{\mathrm{v}}$ In the first year of the Government 2.0 movement most federal government agencies were hesitant to dive into social media. On the federal level, the Transparency and Open Government memo was quickly followed by a series of necessary regulations and policy documents. In December 2009, the Office of Management and Budget (OBM) followed up with an "Open Government Directive" that directed the executive departments and agencies to take specific actions to implement the principles of transparency, participation and collaboration along the lines of the following activities: ${ }^{\mathrm{vi}}$

- Publish Government Information Online 
- Improve the Quality of Government Information

- Create and Implement the Culture of Open Government

- Create an Enabling Policy Framework for Open Governments

- Create Open Government Plan including a

flagship initiative

In April 2010 all federal executive departments

and agencies published an Open Government plan. ${ }^{\text {vii }}$

The results were evaluated in an Open Government

OPEN GOVERNMENT DASHBOARD

Dashboard - publicly highlighting the performance of each agency. One of the early flagship initiatives of the Open Government Initiative is data.gov - a website designed to share large government data sets. ${ }^{\text {viii }}$ It provides the playground for citizens to use government data and to combine data with tools such as OpenStreetMap to create useful and innovative applications for citizens to digest the data. In September 2010, the President renamed his Open Government Initiative and labeled it the "Accountable Government Initiative" outlining its performance management, detailed strategy and key initiatives. ${ }^{\mathrm{ix}}$

Other regulations and conditions were necessary to foster the adoption of new collaborative technologies, such as the Terms of Service Agreements (ToS) with social network services providers prepared by the U.S. General Services Administration (GSA). ${ }^{\mathrm{x}}$ The ToS resolve any legal concerns that agencies discovered in the standard terms and conditions, such as liability limits, endorsements, Freedom of Information, or governing law. On similar path of acceptance, state government authorities have also participated in successful negotiations with service providers in order to modify social media service terms. These negotiations have made social media requirements more palatable to the needs of local and state governments. 
At about the same time, the Department of Defense (DOD) established a policy and assigned responsibilities for the responsible and effective use of Internet-based capabilities, including social networking services. ${ }^{\mathrm{xi}}$ This directive-type memorandum 09-026 paved the way for many other agencies to establish their own social media strategy and policy documents regulating how to use social media in more effective and efficient ways in their own agencies. ${ }^{\text {xii }}$

This was followed by the National Archive and Records Administration's social media records keeping guidelines, ${ }^{\text {xiii }}$ as well as the recent changes in the cookie policy that allow government agencies to collect user data 2010). ${ }^{\text {xiv }}$ On April 14, 2010, the Library of Congress announced that it had acquired the entire Twitter archive - a big step forward in reducing some of the hesitation social media directors especially in the federal department were facing: up to that point it was unclear how to keep Twitter messages - or any messages created on social networking services - for public record keeping purposes. ${ }^{\mathrm{xv}}$ 

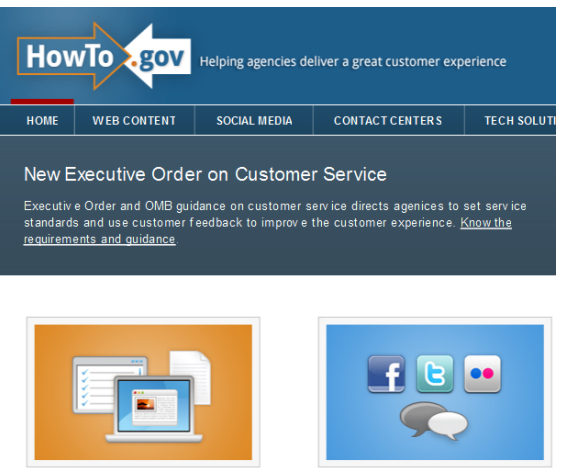

Web Content Federal web require ments, content
management, usability, analytics.
acces sibility, web witing, search..

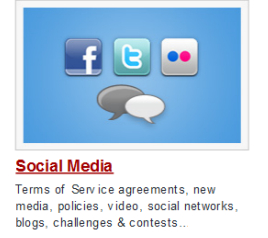

The Open Government Initiative also made a few organizational changes necessary, building up capabilities to better guide the use of new technologies as a result of the above mentioned directives and regulations. In a testimony before the

Committee on

Oversight and Government Reform, U.S. House of

Representatives in July 2010, Associate Administrator

McClure outlined how the General Services

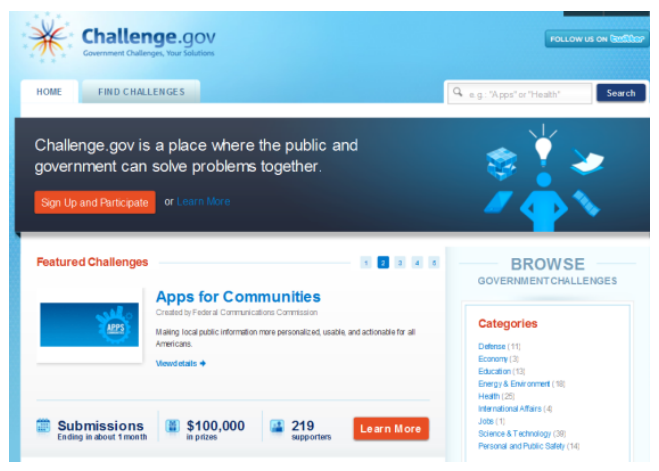

Administration (GSA) can help government with the implementation of new technologies for citizen inclusion and collaboration. ${ }^{\mathrm{xvi}}$ As a result, GSA has created the "Center for New Media and Citizen Engagement" as the central entity to provide guidance on the use of new media. ${ }^{\text {xii }}$ The efforts culminated in a new platform called "HowTo.Gov" that provides agencies with stepby-step guides on how to present web content, a list of preselected and vetted tools to use for different types of initiatives, software downloads and instructions on how to customize and administer social media tools from a strategic and administrative perspective. A similarly important guiding platform is called "Challenge.gov" that helps agencies to set up crowdsourcing and ideation applications. Other guidance comes from PlainLanguage.gov on how to present content on different social media channels to increase inclusion and diffusion of government practices. 
Knowledge is not only crowdsourced from citizens - instead, innovative knowledge needs to make its way into government from many

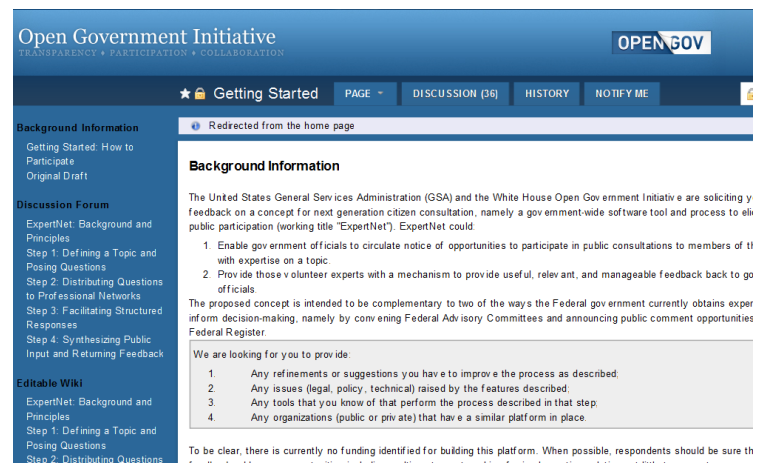
different directions. As an example, the White House Open Government Initiative is using a Wiki to crowdsource expert opinions on how to increase transparency, collaboration and participation (see http://expertnet.wikispaces.com).

Adoption or diffusion of Government 2.0 practices on the state and local level can be observed only on a case-by-case basis and it follows a "just-do-it" mentality with a lot of trial and error. Local governments are under no obligation to emulate federal or state laws and oftentimes set their own standards and regulations for the adoption of social media applications. There is little guidance beyond the federal and state level. Recently, the National Association of CIOs has published toolkits and some guidance for the state level CIOs. ${ }^{\text {xviii }}$

Today, in addition to a growing comfort level among formal agencies, a parallel movement is also observable on the citizen side. So-called civic hackers, citizen journalists, citizen scientists or what some might call "Alpha Geeks" with a vested interest in government are using social media tools with ease and are creating mash-ups using free and open source tools (such as Wikis to co-create content). 
One of these influential developments is the Open311 movement - a collaborative effort to create open standards for 311 services. ${ }^{\text {xix }}$ Open 311 services connect 311 data collected by government with location-based data to create more effective public services. For example, CrimeReports.com works with data police departments collect and displays it on a map. ${ }^{\mathrm{xx}}$

The Government 2.0 movement therefore does not only include government innovations, but

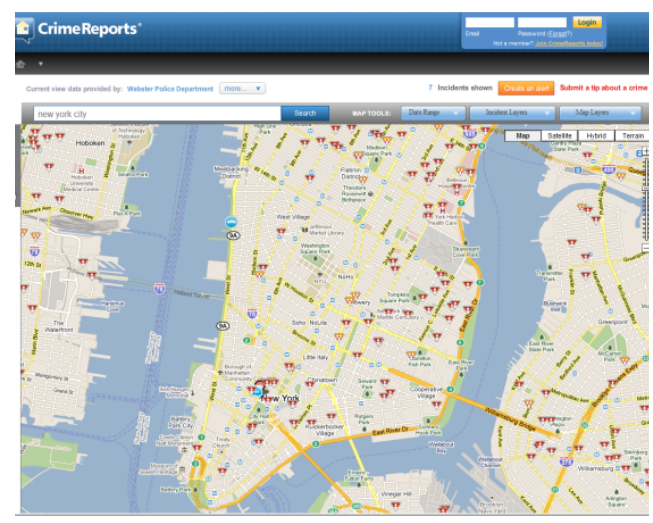
also innovations that are crowdsourced among citizens or civic hackers. So-called Government 2.0 barcamps or unconferences helped to organize the movement and resulted in initiatives, such as CrisisCommons.org, but also startup opportunities such as SeeClickFix.com to engage citizens in community issues. These examples show that Government 2.0 has developed itself from a "Wild West" of the use of open data and social media applications to an organized movement and even a convergence and consolidation with tangible outcomes, such as public services, with value for all citizens.

Nevertheless, Government 2.0 is still in its infancy and can mainly be observed in form of highly public flagship initiatives on the federal government level. A recent report of the Government Accountability Office (GAO) states many of the still existing challenges in federal agencies' use of Web 2.0 technologies. ${ }^{\text {xi }}$ 


\section{Endnotes}

i See http://www.governing.com/topics/technology/Working-in-Wiki.html and http://www.cio.com/article/450636/How_Vivek_Kundra_Fought_Government_Waste_O ne_Google_App_At a Time for more information

ii See http://www.munigov.org/ for more information.

iii Obama, B. (2009). Transparency and Open Government: Memorandum for the Heads of Executive Departments and Agencies. Whitehouse Blog. Retrieved from

http://www.whitehouse.gov/the press office/TransparencyandOpenGovernment Obama, B. (2009). Transparency and Open Government: Memorandum for the Heads of Executive Departments and Agencies. Whitehouse Blog. Retrieved from http://www.whitehouse.gov/the_press_office/TransparencyandOpenGovernment/

v Bretschneider, S. I., \& Mergel, I. (2010). Technology and Public Management Information Systems: Where have we been and where are we going. In D. C. Menzel \& H. J. White (Eds.), The State of Public Administration: Issues, Problems and Challenges (pp. 187-203). New York: M.E. Sharpe, Inc.

vi See http://www.whitehouse.gov/omb/assets/memoranda_2010/m10-06.pdf for the full text of the Open Government Directive, published December 8, 2009.

vii See http://www.whitehouse.gov/open/around for an overview of the status of Open Government plans in 2010.

viii See: http://www.data.gov and for policy insights: http://www.data.gov/documents/data gov conops v1.0.pdf.

${ }^{\mathrm{ix}}$ See Accountable Government Initiative memo: http://www.whitehouse.gov/the-pressoffice/2010/09/14/presidential-memorandum-accountable-government-initiative published on September 14, 2009.

x GSA. (2010). Landmark Agreements Clear Path for Government New Media. GSA \#10572, from http://www.gsa.gov/portal/content/103496

xi See DOD Directive-type memorandum (DTM) 09-026 - Responsible and effective use of Internet-based Capabilities, available online: http://www.defense.gov/releases/release.aspx?releaseid=13338 One remarkable example is the social media handbook of the U.S. Army http://www.carlisle.army.mil/dime/documents/Army\%20Social\%20MediaHandbook Jan 2011.pdf).

xiii Sunstein, C. R. (2010). Social Media, Web-Based Interactive Technologies, and the Paperwork Reduction Act. 7. Retrieved from http://www.whitehouse.gov/sites/default/files/omb/assets/inforeg/SocialMediaGuidance 04072010.pdf

Orszag, P. R. (2010). Guidance for Agency Use of Third-Party Websites and Applications - Memorandum for the Heads of Executive Departments and Agencies. $M$ 10-23 Retrieved from http://www.whitehouse.gov/sites/default/files/omb/assets/memoranda_2010/m10-23.pdf. And: NASCIO (2011): NASCIO and Attorneys General Negotiate Model Facebook Agreement for State Government Use, available online: http://www.nascio.org/newsroom/pressrelease.cfm?id=93, last accessed on 04/06/2011. 
xv Library of Congress announces acquisition of Twitter archive. Available online:

http://twitter.com/\#!/librarycongress/status/12169442690.

xvi See for the full testimony: http://159.142.75.50/portal/content/158009.

xvii See GSA Center for New Media and Citizen Engagement:

http://www.gsa.gov/portal/content/140445

xviii See http://www.nascio.org/

xix See Open311 http://open311.org/learn/ to learn more about the Open311 movement.

xx See Crime Reports: http://www.crimereports.com.

xxi See http://www.gao.gov/new.items/d10872t.pdf for a detailed report about the challenges of the use of social media in the federal government. 